\title{
Inculcating Tsunami Awareness in a Mathematics Lesson: Improving Students' Collaborative Problem Solving via Lesson Study
}

\author{
Madihah Khalid ${ }^{1}$, DkHaslinah Pg. Haji Ali $^{2}$ \\ ${ }^{1}$ Kulliyyah of Education, International Islamic University Malaysia \\ ${ }^{2} S R$ DMW Lambak, Brunei Darussalam
}

\begin{abstract}
The past two cycles of PISA have reflected the demands of the skills and competencies that many countries desire their future generations to possess. Among these competencies, students' financial literacy, problem solving, and communication skills have emerged to be as important as their reading and quantitative literacy (OECD, 2013). Problem-solving, along with other $21^{\text {st }}$ century skills can be inculcated in the students by using the problem-solving pedagogy. However, teachers who are not used to teaching mathematics via problem solving need to experience the pedagogy themselves and this can be best achieved by implementing Lesson Study. A Lesson Study research study was conducted to look at collaborative problem solving in the teaching of the topic on "rate" to year 5 students. Results showed that students benefited from their lesson in terms of increased knowledge of the problem context and the ability to apply knowledge of rates in finding the best solution that the problem posed. Consequently, Lesson Study was found to help enhance teachers' pedagogical content knowledge. It helped them produce effective lesson plans that incorporated student-centred authentic lessons that also integrated values, use of technology and students' creativity in problem solving.
\end{abstract}

Keywords: Lesson Study, meaningful learning, $21^{\text {st }}$ century skills, problem solving approach, Higher Order Thinking Skills,

\section{Introduction}

It was stated in the Malaysian Education Blueprint Annual Report 2013 (MOE, 2013) that there was a concern with students' performance on the Programme for International Student Assessment (PISA) as well as the Trends in International Mathematics and Science Study (TIMSS). In both assessments, Malaysian students' mean scores were not as expected when compared to the international average. It was also noted that both tests assess students for higher order thinking skills (Chen, 2013; Tang, 2014). Many of the questions encountered by the students were problem-solving types of questions which are authentic problems set in a real-world setting, especially the problems in PISA.

The Annual Report document also highlighted the need for improving the quality of education in Malaysia and listed the future trends that specify the goals of teaching and learning for the curricular materials. Among the pedagogies listed were student-centred learning that should incorporate Higher Order Thinking Skills (HOTS). HOTS was defined as "the ability to apply knowledge, skills and values while reasoning and reflecting to solve problems, make decisions, innovate and create.” (MOE, 2013, p. 50). 
The Annual Report document also stated that in a benchmarking report of 2013, Pearson International suggested the need for "conceptual thinking of big ideas in Science and Mathematics to be integrated into the Malaysian curriculum" (pp. 50). Therefore the Ministry will direct that HOTS and $21^{\text {st }}$ century skills are highlighted explicitly in the curriculum and learning materials of the schools. Also MOE will continue to provide Continuous Professional Development with regards to the latest teaching and learning techniques to promote students' active learning. All of these will be done in an attempt to also improve Science, Technology, Engineering and Mathematics (STEM) curriculum based knowledge and skills of STEM teachers.

As mentioned above, among the important $21^{\text {st }}$ century skills that can be inculcated in our students are collaboration, communication and technology fluency skills. So how do we integrate and make sure that all of these aspects are present in problem-solving classes? How do we determine that students are taught these skills in our classroom? Maybe these skills can be inculcated by teaching through collaborative problem-solving classes (or collaborative problem-based learning) that also practice the inquiry-learning approach. In these kind of classes, assessment can also be accomplished concurrently.

Collaborative problem solving is defined by PISA (OECD, 2013, p. 6) as “...the capacity of an individual to effectively engage in a process whereby two or more agents attempt to solve a problem by sharing the understanding and effort required to come to a solution and pooling their knowledge, skills and efforts to reach that solution." The framework used by PISA for the 2015 assessment covers students' collaborative problem solving competencies in terms of "establishing and maintaining shared understanding, taking appropriate action to solve the problem" and also "establishing and maintaining team organization" (OECD, 2013, p. 12). According to Cazden and Beck (2003, p. 165), "... what counts as knowledge has shifted away from inert information passively received from books and teachers toward dynamic understanding that is collaboratively constructed in discussion among students".

However, designing this kind of lesson is not easy for teachers who are not used to teaching this way. Therefore, Lesson Study (or jugyokenkyu in Japanese) can then be employed so that teachers, in the presence of a "knowledgeable other/s", can collaborate to write effective lesson plans based on the criteria selected, try out the lesson in a real setting, observe the "research lesson" and reflect (with comment/critique from observers) accordingly to improve 
the lesson plan, and repeat the process again until a satisfactory lesson is successfully executed. The final step would be writing the report of the completed study.

Lesson Study has been practiced in Japan for more than 130 years (Shimizu, 2006) and it was said to be the main factor that enabled teachers in Japan to teach in a manner that incorporated most of the best practices in teaching. Japanese teaching focused on teaching for conceptual understanding, and Japanese teachers participated in the ongoing, incremental, and continuous improvement of their teaching (Stigler \& Hiebert, 1999). Besides practicing Lesson Study at three different levels - school, district and national levels, teachers also observe each other on a regular basis outside Lesson Study time (Jackson, 2013). Nowadays, Lesson Study is being practiced by more than 40 countries around the world (Burghes \& Robinson, 2009). It is being practiced in places as far away as countries in South America, North America, Asia, Africa, Australia, Europe and even in Russia. In Malaysia, it was documented that Lesson Study started as a research study for Master and PhD in 2004 (Cheah \& Lim, 2010). Now, teachers has started implementing Lesson Study in schools in the Penang and the Klang areas. Lesson Study is seen as an effective continuous professional development model because teachers are fully involved in the process as compared to traditional continuous professional development where teachers took a more passive role.

A study by Suhaili and Khalid (2011) stated that one of the many positive outcome of Lesson Study was as an effective alternative continuous professional development. Fernandez and Chokshi (2002) emphasized that Lesson Study was more a process of knowledge building than searching for the "best practices". Lesson Study is a process for creating deep and grounded reflection about the complex activities of teaching that can be shared and discussed with other members of the profession.

\footnotetext{
Improving something as complex and culturally embedded as teaching requires the efforts of all players, including students, parents, and politicians. But teachers must be the primary driving force behind change. They are the best positioned to understand the problems that students face and to generate possible solutions (Stigler \& Hiebert, 1999, pp 135)
}

\section{The Study}

This study is an attempt to examine students' behavioural changes which includes collaborative problem solving skills, tsunami awareness, and understanding of the topic "rate", while, teachers' reactions and acceptance of "Lesson Study" were also evaluated. A intervention research study was conducted to evaluate students' collaborative problem solving ability via a contextual real-life problem of a tsunami, similar to what happened during the tsunami of 2004. Many of the students were not aware of the tragedy since they were still babies when that 
happened and tsunamis and earthquakes are a rare phenomenon in Malaysia. The topic of "rate" was chosen for the mathematics lesson because when the study was conceptualized, the researchers knew that by the time the study was implemented, the students in Year 5 would be learning about rate. Lesson Study was used as a tool for this action research. Lesson Study offers the teacher the chance to be directly involved in the collaborative lesson planning under the guidance of the knowledgeable others. It also offers the opportunity for teachers to improve their lesson planning based on critical comments and to repeat the cycle with the improved lesson plan with other classes, in the proximity of a few weeks.

Lesson plans focusing on the student-centred approach to learning was designed with elements like problem-posing, cooperative learning, creative thinking, use of Information Communication Technology (ICT), contextual problem, performance assessment etc. included in the lesson. An interactive d-book was designed so that teachers could look at the task-outline and the suggested solution. The d-book is an interactive electronic book created using dbookPro software. The main purpose of setting the problem in the d-book was to make sure that students could work on the problem interactively where learning becomes more real and fun for them. Hence, the d-book acts as another representation utilized to enhance students' understanding of mathematics. [The d-book can be accessed at http://math-info.criced.tsukuba.ac.jp/ museum/dbook site/ Burunei-pub/files/EText.html. ]

\section{Research Questions (RQ)}

In order to achieve the objectives of the study, the following research questions were formulated to guide the research:

1. To what extent does the lessons improve students' knowledge on Tsunami and "rate"?

2. How do students' behave during collaborative problem solving?

3. What is the impact of Lesson Study on the school teachers?

\section{Methodology}

The sample for this research was composed of 3 classes, consisting a total of 58 Year 5 students. This study employed a mix methods research methodology, collecting both qualitative and quantitative data, to maintain validity and reliability. Students were given a pretest one week before the teaching started and a post-test later after one and a half month. The pre and post- test questions tested students' knowledge of tsunami and 'rate'. Lessons started with class A after lesson planning was completed. The research lesson implemented was observed by $6-$ 
8 teachers and officers from the Ministry of Education, followed by a discussion and reflection session. A lesson plan was improved based on feedback given during the reflection session and the cycle was repeated with class B and subsequently with class C.

Quantitative data was collected through using observation checklists on aspects of teaching and learning (such as content delivery, lesson presentation, strategy and resources used, classroom communication and assessment. These were rated on the Likert scale of 1 to 5 ranging from "not at all" to "very high" respectively), checklist for collaborative problem solving on how they behave during collaborative problem solving (rated on a Likert scale of 1 to 5 from never to always respectively) and pre-test and post-test. The tests were made parallel so as to make sure that students did not memorize the answers from the pre-test to answer the post-test and consisted of questions about tsunami and "rate". Qualitative data was collected through observations of video recordings of the lessons and the reflection stage for every cycle, researcher's field notes, and teachers' interview.

SPSS was used to analyse the quantitative data collected. Paired sample $t$-test was used to compare the learning outcomes of students' achievement and behaviours among the three lessons. Students' performance data were also analysed using ANCOVA. This method of analysis enabled the authors to compare students' mathematics achievements and awareness of tsunami based on post-test item scores by controlling the covariate (in this case, the pre-test results). Descriptive statistics were used to compare the learning outcomes of students' performance in problem-solving activity from the observation data. Paired t-test was also conducted to determine the differences of students' performance between the three classes. Observation field notes and interviews were transcribed, and categorised into identified themes to support the quantitative data.

\section{Lesson Format}

Set Induction: Students were first shown a very short video of a tsunami hitting the shores of some countries. They were asked to discuss what they saw, how it occured and what can be learnt from it. After discussion, the students were shown a video on the cause of tsunami, due to the movements of tectonic plates.

Main Lesson: Then the students were shown a video of a girl, named Tilly, who managed to take prompt action and save several lives when a tsunami struck in 2004, because 
she remembered the early warning signs of a tsunami that she learnt in her geography lesson. Then, the children were asked to solve the following problem:

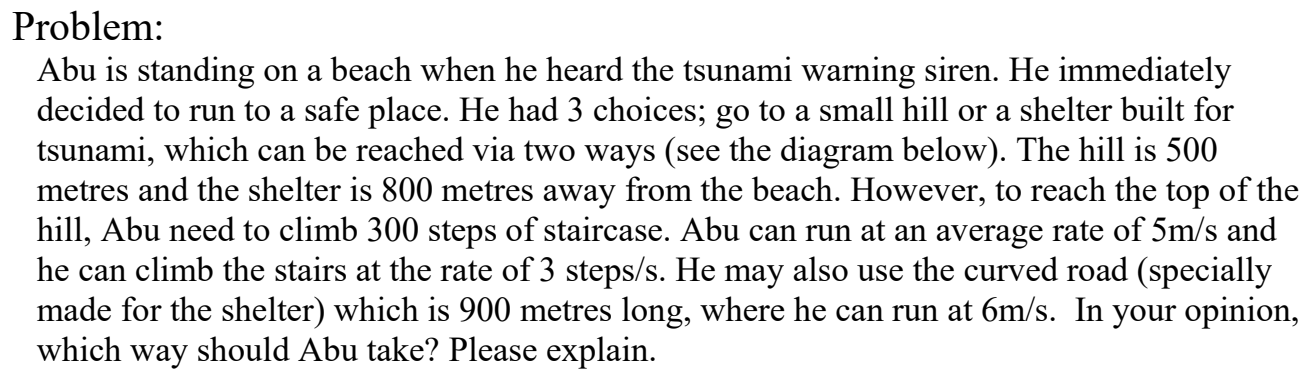

The problem was made open so there were several ways to approach the solution to the problem were possible. Students were encouraged to pose their own problems/questions from what they understood and some did come up with very good questions. Among the questions posed by the students were: "To save myself, do I really need to go to the top of the hill?" "What is the normal height of the tsunami?" "What is the speed of the tsunami?"

During the problem solving process, students were made to work in groups so that their collaborative problem solving could be assessed. Observers were asked to rate the students' problem solving ability in terms of understanding the problem, planning and executing the process to solve the problem, the final answer to the problem and how they communicate their answer with their friends during the activity. Finally each group was required to present their result.

Closure: Students were asked to state what they learnt in the lesson and the teacher finally summarized the lesson at the end.

\section{Results}

Answering RQ 1. Paired t-test on students' achievement tests (pre-test and post-test), found that there was improvement for every class with Class B in Lesson 2 being statistically significant at $\mathrm{p}<0.05$. Every class seemed to perform better in their post-test which suggest students' improved awareness of Tsunami and problem solving ability in the topic of "rate". 
Table 1

Paired t-test showing improvement from pre to post-test of the three classes

\begin{tabular}{llllllll}
\hline & & Mean & $\mathrm{N}$ & $\begin{array}{c}\text { Std. } \\
\text { Deviation }\end{array}$ & $\mathrm{t}$ & $\mathrm{df}$ & Sig. \\
\hline Lesson 1 & Pre-Test & 1.15 & 13 & 0.69 & -1.67 & 17 & 0.12 \\
(Class A) & Post Test & 1.77 & 13 & 1.30 & & & \\
& & & & & & & \\
Lesson 2 & Pre-Test & 3.38 & 24 & 1.31 & -2.07 & 23 & 0.05 \\
(Class B) & Post Test & 4.04 & 24 & 1.65 & & & \\
& & & & & & & \\
Lesson 3 & Pre-Test & 2.11 & 19 & 1.24 & -1.02 & 18 & 0.32 \\
(Class C) & Post Test & 2.53 & 19 & 1.58 & & & \\
\hline
\end{tabular}

The ANCOVA test performed on the mean scores (to compare the effect of the lesson on the students' achievement when the pre-test was covariate-out) revealed near but no significant improvement of the test results between each lesson (or class). The indication from the qualitative data showed that students seemed to be engrossed in discussion of a tsunami and further examination of the pre and post test showed that students answered the questions on tsunami better than the questions on "rate". Therefore, we consider the aim of making students aware of tsunami as somewhat successful in terms of improved knowledge about a tsunami.

Table 2

ANCOVA showing the Tests of Between-Subject Effects

\begin{tabular}{|c|c|c|c|c|c|c|c|c|}
\hline Source & $\begin{array}{c}\text { Type III Sum of } \\
\text { Squares }\end{array}$ & Df & $\begin{array}{l}\text { Mean } \\
\text { Square }\end{array}$ & $\mathrm{F}$ & Sig. & $\begin{array}{l}\text { Partial Eta } \\
\text { Squared }\end{array}$ & $\begin{array}{l}\text { Noncent. } \\
\text { Parameter }\end{array}$ & $\begin{array}{c}\text { Observed } \\
\text { Power }^{\mathrm{b}}\end{array}$ \\
\hline Corrected Model & $64.034^{\mathrm{a}}$ & 3 & 21.34 & 9.74 & .000 & .36 & 29.22 & 1 \\
\hline Intercept & 38.14 & 1 & 38.14 & 17.40 & .000 & .25 & 17.40 & .98 \\
\hline PreTest & 14.04 & 1 & 14.04 & 6.41 & .014 & .11 & 6.41 & .70 \\
\hline Class & 11.02 & 2 & 5.51 & 2.51 & .091 & .09 & 5.03 & .48 \\
\hline Error & 113.97 & 52 & 2.19 & & & & & \\
\hline Total & 682.00 & 56 & & & & & & \\
\hline Corrected Total & 178.00 & 55 & & & & & & \\
\hline
\end{tabular}

Answering RQ 2: Figures 1and show the graphs of mean scores obtained from the observation checklist of the observers. It seemed to show that in most cases, lesson 2 have the highest mean for all categories as compared to Lessons 1 and 3. It is to be reminded that lesson 2 consist of more able students and hence is reflected in the mean scores. Figure 1 shows slight improvements in terms of presentation and strategy of the lesson as the lesson plans were improved. Scores on resources seemed to decrease steadily as the lesson plans were improved, we decided to concentrate more on the problem solving part and shorten the three videos played during the lessons. The variations exhibited for other categories of the lesson was mainly 
attributed to the level of students' ability taught in each lesson. Since lesson 2 consisted of more able students, more content was taught, they seemed to communicate more with the teacher and among themselves, they reacted better to the questions in the assessment part and exhibited desired pupil behavior.

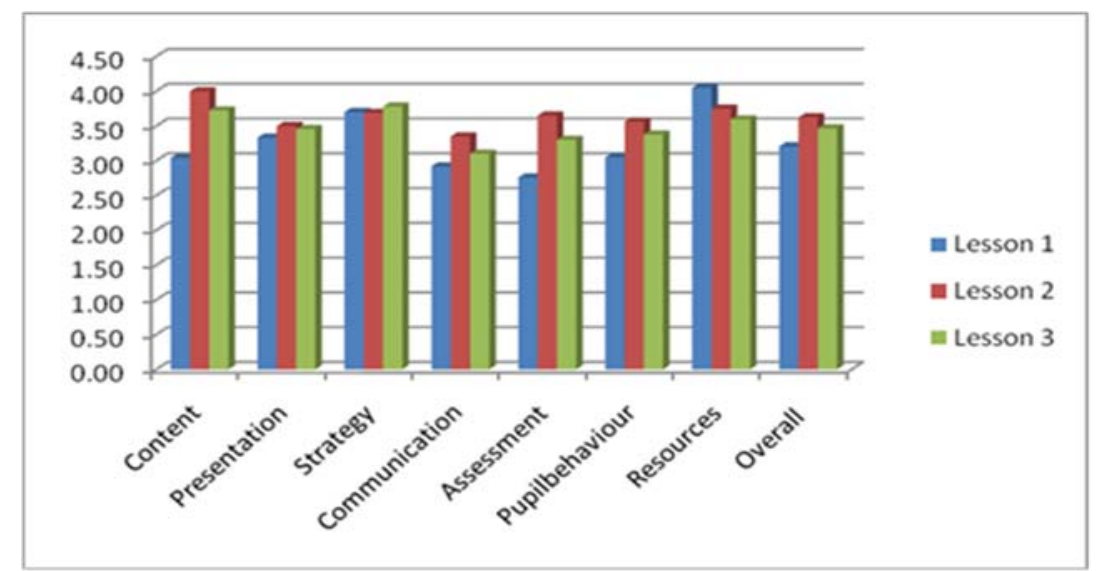

Figure 1. Mean score of all categories over the three lessons from lesson observation checklist.

For students' problem solving abilities which were measured using a rubric in terms of Understanding the problem; Solving the problem; Outcomes of activities and Communication (rated from 1 to 4 for Needs Improvement, Satisfactory, Good and Excellent respectively), the range is between needs improvement to satisfactory level which still shows weak authentic problem solving techniques among the students. Again, in this case, students from Lesson 2 seemed to be performing better than the others.

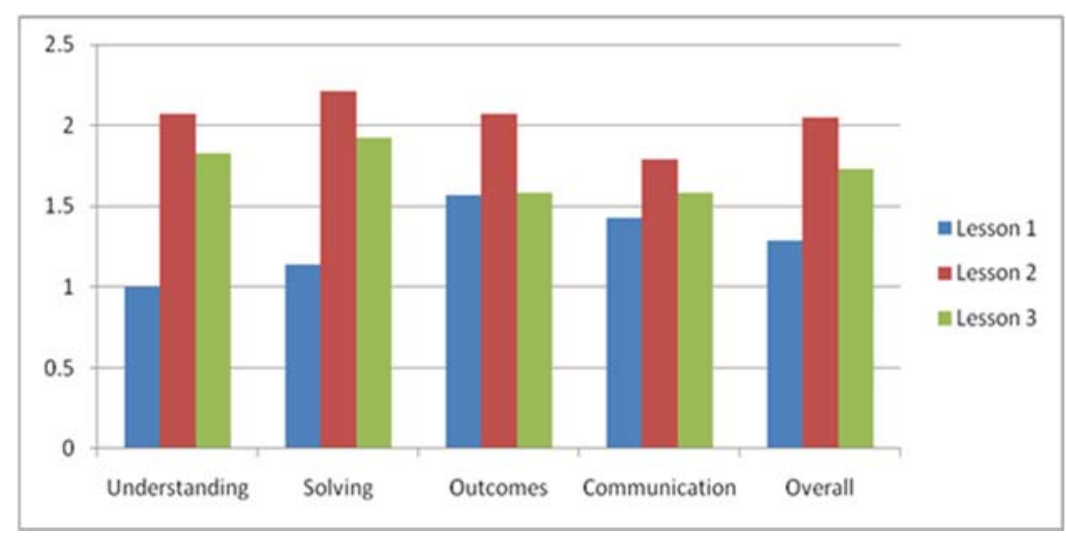

Figure 2. Mean rubric scores in each category for all the three lessons

Table 1 shows the score from collaborative group work checklist rated by the observers present during the lesson implementation part of Lesson Study. The mean score for each item is from 1.71 to 2.83 , which is between rarely to occasionally. From this result and the result from above, it may be deduced that students' collaborative problem solving skills is in the developing stage. 
Table 2

Mean scores for each item is from 1.71 to 2.83

\begin{tabular}{|c|c|c|c|c|c|c|}
\hline Item & statement & $\mathrm{N}$ & $\begin{array}{l}\text { Lesson } \\
1\end{array}$ & $\begin{array}{l}\text { Lesson } \\
2\end{array}$ & $\begin{array}{l}\text { Lesson } \\
3\end{array}$ & $\begin{array}{c}\text { Overall } \\
\text { Mean }\end{array}$ \\
\hline Item 1 & $\begin{array}{l}\text { Negotiated roles and responsibilities of each } \\
\text { group member. }\end{array}$ & 24 & 1.25 & 2.25 & 1.63 & 1.71 \\
\hline Item 2 & $\begin{array}{l}\text { Was receptive to peer questions and } \\
\text { criticism. }\end{array}$ & 24 & 1.88 & 3.00 & 2.38 & 2.42 \\
\hline Item 3 & Listened to each other' opinions and ideas. & 24 & 2.38 & 2.88 & 2.50 & 2.58 \\
\hline Item 4 & $\begin{array}{l}\text { Give appropriate time to allow other group } \\
\text { members think before they answered. }\end{array}$ & 24 & 2.38 & 2.63 & 1.88 & 2.29 \\
\hline Item 5 & Contributed ideas and opinions. & 24 & 3.00 & 3.38 & 2.13 & 2.83 \\
\hline Item 6 & $\begin{array}{l}\text { Encouraged the involvement of all group } \\
\text { members. }\end{array}$ & 24 & 2.00 & 2.63 & 2.25 & 2.29 \\
\hline Item 7 & $\begin{array}{l}\text { Respected and accepted the contribution of } \\
\text { each group member. }\end{array}$ & 24 & 2.38 & 2.75 & 2.25 & 2.46 \\
\hline Item 8 & Enabled group to reach consensus. & 24 & 2.00 & 2.63 & 1.75 & 2.13 \\
\hline Item 9 & $\begin{array}{l}\text { Modified personal thinking to incorporate } \\
\text { the ideas of the others or new information. }\end{array}$ & 24 & 2.00 & 2.75 & 1.75 & 2.17 \\
\hline Item 10 & $\begin{array}{l}\text { Completed the assigned task within the } \\
\text { given amount of time. }\end{array}$ & 24 & 1.50 & 2.63 & 1.63 & 1.92 \\
\hline Item 11 & $\begin{array}{l}\text { Completed individual commitment to the } \\
\text { group. }\end{array}$ & 24 & 1.63 & 2.63 & 1.63 & 1.96 \\
\hline Mean & & 24 & 2.03 & 2.74 & 1.98 & 2.25 \\
\hline
\end{tabular}

RQ 3. Most teachers interviewed agreed that they learnt a great deal during the Lesson Study process in terms of knowledge sharing especially of pedagogical content knowledge, content and curriculum which translated in their ability to design constructivist, studentcentered instructions. A teacher involved in lesson planning remarked that working together had broadened her knowledge of the mathematics content and subject matter. Another teacher said that teaching and observing the research lesson made her more critical in choosing the right teaching activities that helped students to understand and think mathematically. One teacher also commented that the whole process of Lesson Study has been one of the most beneficial activity she had been involved with, as she learnt about translating the curriculum into effective and interesting task.

\section{Discussion}

Students enjoyed the lesson introduction because it was made more real and interesting with the presentation of videos. The impact of the videos made pupils feel involved in real-life events physically and this led to motivation to discuss it. The lesson was well-linked starting from the video on tsunami hitting Japan, followed by discussion on what causes tsunami. The second video from UN International Strategy for Disaster Reduction was about how a girl 
manage to save the lives of a few families on holiday in Thailand because she was able to recall the early warning signs of tsunami learned from her geography class. Subsequently, students were led to solve the "saving life" problem on mathematics. The problem was posed in a real life context and this motivated them to solve it. The problem was made more real and interactive using the Dbook. Students were found to discuss tsunami even after the class ended. Overall, the lesson was successful in making students visualize, communicate, reason and think mathematically although this were only exhibited fully by some students. Some were also able to exhibit their computational skills and understanding of rate in obtaining the time taken for each path and hence chose the one that required the shortest time. Students' creativity was evident during the lesson. They used various methods in calculating the answer, repeated addition (proportion), multiplication, division and a mix of operations.

The teachers were also engaged in the tasks given starting from lesson planning until the writing of the report. The collaborative nature of Lesson Study and the demand of preparing exemplary lesson made the teachers think creatively and critically on how to design good lessons. They claimed that the pedagogical content knowledge that they gained through Lesson Study was more valuable than the normal professional development courses.

\section{Conclusion}

It is important to note that the findings are only applicable to the schools involved and the writers make no claims to them being universally applicable to other Malaysian schools. However for readers, their value lies in the possibilities of replication and adaptability. With those qualifications, it was apparent from this research study that, Lesson Study has made it possible for teachers to plan lessons that:

- Made students aware of natural disasters and learn from it.

- Were more authentic by incorporating real-life events to problem-solving classes.

- Incorporated the use of ICT - videos and interactive Dbook that made the activities more interesting to the students.

- Allowed students to be creative because they had the freedom to choose multiple methods in the open-ended problem presented.

- Motivate students to learn because they felt the ownership of learning. 
In this limited study, the Lesson Study process helped the teachers to discuss the lesson plan and to prepare improved lessons using a constructivist approach. Teachers also experienced how, by cooperation and collaboratively helping each other, they were able to increase their pedagogical-content-knowledge, knowledge on curriculum and the content.

Liptak (2002) said that like most good investments, we expect that the growth and dividends from the time we invest in Lesson Study will accrue gradually over a long period of time. Improving our teaching in depth is hard, time-consuming work, which needs to be done collaboratively and in a supportive setting and the researchers believe that this will happen in our country.

\section{References}

Burghes, D., \& Robinson, D. (2009). Lesson Study: Enhancing Mathematics Teaching and Learning. London: CfBT Education Trust.

Cazden, C Cazden, C. B. \& Beck, S. W. (2003). Classroom discourse. In A. C. Graesser, M. A. Gernsbacher \& S. R. Goldman (Eds.), Handbook of discourse processes (pp. 165197). Mahwah, NJ: Lawrence Erlbaum Associates

Cheah U. H., \& Lim C. S. (2010). Disseminating and Popularising Lesson Study in Malaysia and Southeast Asia. Paper delivered at the APEID Hiroshima Seminar "Current Status and Issues on Lesson Study in Asia and the Pacific Region.

Chen, K. S. (2013, December 8). Poor show in PISA ranking. Retrieved from The Star Online: http://www.thestar.com.my/News/Education/2013/12/08/Poor-show-in-Pisarankings/

Fernandez, C. \& Chokshi, S. (October 2002). A practical guide to translating Lesson Study for a U.S. setting. Phi Delta Kappan, 84(2), 128-134.

Jackson, B. (2013, October 3). Why Other Countries do Better in Math. Retrieved from The Daily Riff: http://www.thedailyriff.com/articles/why-other-countries-do-better-in-math520.php

Liptak, L. (2002). It's a matter of time: Scheduling Lesson Study at Paterson, NJ School 2. Patterson, New Jersey: RBS

Ministry of Education Malaysia (MOE) (2013). Malaysia Education Blueprint Annual Report, Ministry of Education Malaysia. Putrajaya: Author.

OECD (2013). PISA 2012 Assessment and Analytical Framework: Mathematics, Reading, Science, Problem Solving and Financial Literacy. Bangkok: OECD Publishing. http://dx.doi.org/10.1787/9789264190511-en

Programme for International Student Assessment (PISA) (2013). PISA 2015 Draft collaborative problem solving framework. Retrieved $20^{\text {th }}$ July, 2014 from http://www.oecd.org/pisa/pisaproducts/Draft\%20PISA\%202015\%20Collaborative\%20Pr oblem $\% 20$ Solving\%20Framework\%20.pdf

Shimizu, S. (2006). Professional development through Lesson Study: A Japanese case. Paper presented at the APEC International Symposium on Innovation and Good Practices for Teaching and Learning Mathematics through Lesson Study, Khon Kaen, Thailand.

Stigler, J., \& Hiebert, J. (1999). The Teaching Gap: Best Ideas from the World's Teachers for Improving Education in the Classroom. New York: Free Press. 
Suhaili, H. A., \& Khalid, M. (2011). Mathematics Teachers Perception of Lesson Study as a Continuous Professional Development Programme. Journal of Science and Mathematics Education in Southeast Asia, 34, 67-89.

Tang, S. (2014, April 14). Malaysian Students Nowhere Near Top of the Class. Retrieved from Malaysian Business Insider: http://www.businessinsider.my/malaysias-studentsnowhere-near-top-class/\#.VBpvlHlxnIU 